\title{
UJI SITOTOKSIK EKSTRAK TANAMAN GANDARIA (Bouea macrophylla Griff) TERHADAP SEL HeLa
}

\author{
Asep Roni, Amar Maruf, Lia Marliani \\ Fakultas Farmasi Universitas Bhakti Kencana \\ JL. Soekarno- Hatta No. 754, Bandung, Jawa Barat, Indonesia \\ asep.roni@bku.ac.id
}

Received 4 January 2021

Accepted 24 June 2021

\begin{abstract}
Abstrak
Gandaria merupakan tanaman yang berasal dari indonesia terutama maluku yang memiliki akitvitas farmakologis, akan tetapi belum banyak dilihat sebagai objek studi penelitian karena kelangkaannya di Indonesia. Gandaria memiliki kandungan flavonoid, yang terdapat dalam berbagai tumbuhan dan memiliki berbagai aktifitas farmakologis. Salah satu contoh senyawa flavonoid yang terdapat dalam gandaria adalah quercetin dimana quercetin memiliki berbagai efek biologis, salah satunya sebagai antikanker. Kanker adalah penyebab utama kedua kematian menurut WHO pada tahun 2018. Salah satu pengobatan kanker adalah kemoterapi akan tetapi memiliki efek samping yang merugikan oleh karena itu bahan alam berpotensi sebagai salah satu alternatif karena efek sampingnya lebih rendah. Tujuan dari penelitian ini adalah untuk menguji aktivitas sitotoksik ekstrak daun dan batang gandaria terhadap sel kanker serviks HeLa. Metode yang digunakan adalah MTT assay yaitu uji kolorimetri untuk menilai aktivitas metabolisme sel yang dibaca oleh alat ELISA reader pada panjang gelombang $550 \mathrm{~nm}$. Nilai $\mathrm{IC}_{50}$ dari ekstrak etil asetat daun 436,966 $\mu \mathrm{g} / \mathrm{mL}$ dan ekstrak nheksana batang 292,044 $\mu \mathrm{g} / \mathrm{mL}$. Dapat disimpulkan bahwa aktivitas sitototksik paling baik ditunjukan oleh sampel ekstrak n-heksana batang dan tergolong lemah.
\end{abstract}

Kata Kunci: Gandaria, Sel HeLa, MTT assay

\begin{abstract}
Gandaria is a plant originating from indonesia especially Maluku that has the potential to be pharmacological activity, although it has not been widely seen as an object of research study because of its scarcity in Indonesia. Gandaria contains flavonoids which are found in various plants. One of the flavonoids example is quercetin that has various biological effects, one of which is as an anticancer. Cancer is the second leading cause of death according to WHO in 2018. One of the cancer treatments is chemotherapy, but it has adverse side effects, therefore natural ingredients have the potential as an alternative because of their lower side effects. The aim of this study was to examine the cytotoxic activity of leaves and stems of gandaria extracts against HeLa cervical cancer cells. The method used is the MTT assay which is a colorimetric test to assess the metabolic activity of cells read by ELISA reader at a

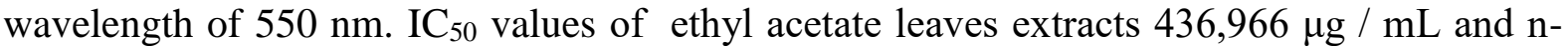
hexane stem extracts $292,044 \mu \mathrm{g} / \mathrm{mL}$. These results indicate that the cytototoxic activity is best showed by n-hexane stem extracts samples and classified as weak.
\end{abstract}

Keywords: Gandaria, HeLa cell, MTT assay. 


\section{Pendahuluan}

Berdasarkan data WHO kanker adalah penyebab utama kedua kematian secara global dan diperkirakan menyumbang 9,6 juta kematian pada tahun 2018. Kanker paru-paru, prostat, kolorektal, lambung dan hati adalah jenis kanker yang paling umum pada pria, sedangkan kanker payudara, kolorektal, paru-paru, leher rahim dan kanker tiroid adalah yang paling umum di antara wanita (WHO, 2018).

Salah satu pengobatan kanker adalah kemoterapi. Kemoterapi digunakan utamanya untuk membunuh sel kanker dan menghambat perkembangannya. Akan tetapi Efek samping kemoterapi muncul karena obat-obatan tersebut tidak memiliki kemampuan membedakan sel kanker yang berkembang pesat secara abnormal dengan sel sehat yang secara normal juga memiliki perkembangan pesat. Oleh karena itu Bahan alam berpotensi sebagai salah satu alternatif untuk pengobatan kanker karena memiliki efek samping yang lebih rendah dibandingkan dengan kemoterapi (Prayetni, 1997).

Sejak dulu pemanfaatan tanaman sebagai bahan obat telah banyak digunakan. Namun hingga sekarang belum semua tumbuhan telah diketahui memiliki potensi sebagai tanaman obat. Salah satu tanaman yang sampai saat ini belum diketahui manfaatnya sebagai tanaman obat ialah tanaman Gandaria. Gandaria (Bouea macrophylla Griff) adalah satu spesies dari suku Anacardiaceae, yang di beberapa daerah di Indonesia disebut dengan berbagai nama yang berbeda. Tumbuhan Gandaria (Bouea macrophylla Griff) dikenal dengan nama daerah Gandoriah (Minangkabau), Barania (Dayak), Jatake, Gandaria (Sunda), Buwa melawe (Bugis), Gondariya (Jawa) ( Heyne, K., 1987) masih sangat terbatas pemanfaatannya, yaitu hanya sebagai sumber buah-buahan. Kayu dari tumbuhan Gandaria ini banyak digunakan untuk membuat alat-alat pertanian, daunnya yang muda digunakan sebagai lalap, buahnya dapat langsung dimakan, dibuat rujak, asinan, dan sari buah-buahan, dipakai sebagai pengganti jeruk nipis atau asam ( Vesheji 1992 ).

Gandaria memiliki kandungan quercetin, flavonoid yang umumnya terdapat dalam berbagai tanaman termasuk bawang, buahbuahan, dan sayuran. quercetin, pada konsentrasi kecil tidak beracun, diketahui memiliki banyak efek biologis yang diakui di mana banyak mekanismenya tetap menjadi misteri. Meskipun sebagian besar informasi yang diketahui tentang quercetin didasarkan pada model in vitro dan murine, ada bukti signifikan bahwa quercetin adalah molekul dengan beberapa sifat yang bermanfaat secara biologis. Bukti ini mendukung peran quercetin sebagai pengobatan untuk kerusakan oksidatif, kanker, peradangan, infeksi bakteri dan virus, penyakit kardiovaskular, dan diabetes. Bukti untuk masing-masing kategori ini bervariasi. Temuan konklusif dari manfaat quercetin, belum menyelesaikan semua uji klinis keras farmasi. Meskipun ada banyak analog quercetin dan flavonoid dengan beragam bukti untuk mendukung klaim mereka (Aaron J. Smith, 2016). Berdasarkan penelitian ekstrak etil dan ekstrak methanol batang gandaria menunjukan penghambatan terhadap bakteri Staphylococcus aureus dan Escherichia coli, yang diduga berasal dari senyawa fenolat (Roni, A. 2019).

Senyawa kimia yang berkaitan dengan metabolit sekunder seperti alkaloid, terpenoid, golongan fenol, flavonoid, kuinon, tanin, saponin banyak terdapat di dalam tumbuhan dan sangat potensial untuk diteliti dan dikembangkan oleh para peneliti Indonesia dalam rangka pencarian obat atau bahan baku obat. Tumbuhan Gandaria masih sangat terbatas pemanfaatannya. Kayu dari tumbuhan Gandaria ini banyak digunakan untuk membuat alat-alat pertanian, daunnya yang muda digunakan sebagai lalap, buahnya dapat langsung dimakan, dibuat rujak, 
asinan, dan sari buah-buahan, serta dipakai sebagai pengganti jeruk nipis atau asam jawa (Isnawati, 2012). Tujuan dilakukannya penelitian ini adalah untuk memberikan informasi apakah Bouea macrophylla Griff memiliki aktivitas sitotoksik atau tidak.

\section{Metode Penelitian}

Metodologi penelitian yang digunakan dalam penelitian ini mepiputi penyiapan bahan, karakterisasi simplisia, penapisan fitokimia, ekstraksi, pengujian aktivitas antikanker MTT assay (3-(4,5-dimetiliazol2-il)-2,5-difeniltetrazolium bromid.

Penyiapan bahan meliputi pengumpulan bahan yang akan digunakan,determinasi, pengolahan bahan sampai jadi simplisia.

Karakterisasi simplisia meliputi pemeriksaan spesifik dan non spesifik antara lain kadar abu total, abu tidak larut asam, kadar sari larut air, sari larut etanol, kadar air dan susut pengeringan. Penapisan fitokimia meliputi pemeriksaan terhadap beberapa senyawa seperti alkaloid, flavonoid, tanin, saponin,kuinon dan steroid.

Ekstraksi dilakukan dengan cara refluks bertingkat menggunakan pelarut n-Heksan,

etil asetat dan metanol. Ekstraksi dilakukan pengulangan sebanyak 3 kali yang masing-masing dilakukan selama 3 jam. Kemudian ekstrak dipekatkan menggunakan rotary evaporator hingga didapatkan ekstrak kental.

Pengujian aktivitas sitotoksik dilakukan dengan metode MTT assay (3-(4,5dimetiltiazol-2-il)-2,5-difeniltetrazolium bromid.

\section{Hasil dan pembahasan \\ Pembuatan dan Karakterisasi simplisia}

Daun dan batang segar dari tanaman Bouea macrophylla Griff (gandaria) yang diperoleh dilakukan sortasi basah untuk memisahkan bahan dari pengotor dan bagian yang tidak digunakan kemudian dicuci dan dibersihkan dari kotoran yang masih menempel pada permukaan daun menggunakan air mengalir lalu tiriskan. Selanjutnya dikeringkan dengan menggunakan oven pada suhu $45^{\circ} \mathrm{C}$, kemudian simplisia yang diperoleh dihaluskan dan serbuk simplisia disimpan dengan baik dalam wadah tertutup dan terlindung dari serangga dan cahaya matahari. Hasil pengolahan bahan dapat dilihat pada tabel 1 .

\section{Tabel 1}

\section{Hasil Pembuatan simplisia Daun dan Batang gandaria (Bouea macrophylla Griff)}

\begin{tabular}{lcc}
\hline \multirow{2}{*}{ Sampel } & \multicolumn{2}{c}{ Bobot Sampel (gram) } \\
\cline { 2 - 3 } & Basah & Kering \\
\hline Daun & 3000 & 1000 \\
\hline Batang & 150 & 119,8445 \\
\hline
\end{tabular}

Karakterisasi simplisia dilakukan dengan tujuan untuk mengetahui kualitas dan mutu simplisia yang digunakan. Parameter yang bisa digunakan antara lain kadar air, kadar abu total, kadar abu larut air, kadar abu tidak larut asam, kadar sari larut air, kadar sari larut etanol, dan susut pengeringan. 
Tabel 2. Hasil Karakterisasi Simplisia

\begin{tabular}{lcc}
\hline \multirow{2}{*}{ Uji Karakterisasi } & \multicolumn{2}{c}{$\begin{array}{c}\text { Hasil Pengamatan } \\
\text { \%(B) }\end{array}$} \\
\cline { 2 - 3 } & $\begin{array}{c}\text { Daun } \\
\text { gandaria }\end{array}$ & $\begin{array}{c}\text { Batang } \\
\text { Gandaria }\end{array}$ \\
\hline Kadar Abu Total & $8,21 \%$ & $2,45 \%$ \\
Kadar Abu Tidak Larut Asam & $2,45 \%$ & $2,1 \%$ \\
Kadar Sari Larut Air & $5,5 \%$ & $3 \%$ \\
Kadar Sari Larut Etanol & $4,15 \%$ & $3,21 \%$ \\
Kadar Air & $5,23 \% *$ & $9,14 \%$ \\
Susut Pengeringan & $9,27 \%$ & $10,58 \%$ \\
\hline
\end{tabular}

Skrining Fitokimia

Skrining fitokimia/ penapisan fitokimia bertujuan untuk mengetahui golongangolongan senyawa yang terdapat didalam simplisia. Pemeriksaan ini meliputi. pemeriksaan alkaloid, flavonoid, steroid/triterpenoid, kuinon, tanin,dan sponin.

Tabel 3. Hasil Penapisan Fitokimia Simplisia

\begin{tabular}{lcc}
\hline \multicolumn{1}{c}{ GOLONGAN } & \multicolumn{2}{c}{ Hasil Pengamatan \%(B/B) } \\
\cline { 2 - 3 } \multicolumn{1}{c}{ SENYAWA } & Daun gandaria & Batang gandaria \\
\hline Alkaloid & - & - \\
Flavonid & + & + \\
Tanin & + & + \\
Kuinon & + & + \\
Saponin & - & + \\
Steroid/triterpenoid & + & + \\
\hline
\end{tabular}

\section{Ekstraksi}

Ekstraksi yang dilakukan pada simplisia batang dan daun gandaria sebanyak 750 gram menggunakan metode refluks dengan cara ekstraksi bertingkat menggunkaan pelarut nheksana, etil asetat dan methanol berdasarkan kepolarannya. 
Tabel 4. Hasil Rendemen Ekstrak

\begin{tabular}{lrcrc}
\hline \multirow{2}{*}{ Pelarut } & \multicolumn{2}{c}{ Daun } & \multicolumn{2}{c}{ Batang } \\
\cline { 2 - 5 } & Ekstrak & Rendemen & Ekstrak & Rendemen \\
\hline N-heksan & $3,55 \mathrm{~g}$ & $2,36 \%$ & $0,2431 \mathrm{~g}$ & $0,24 \%$ \\
\hline Etil Asetat & $4,34 \mathrm{~g}$ & $2,89 \%$ & $0,5644 \mathrm{~g}$ & $0,56 \%$ \\
\hline Methanol & $13,537 \mathrm{~g}$ & $9,02 \%$ & $2,7658 \mathrm{~g}$ & $2,76 \%$ \\
\hline
\end{tabular}

\section{Uji aktifitas Sitotoksik}

Uji aktivitas sitotoksik pada penelitian ini dilakukan untuk mengetahui toksisitas bahan uji daun dan batang gandaria terhadap sel HeLa. Metode yang digunakan adalah MTT assay, yaitu uji kolorimetri yang menggunakan reaksi redoks yang terjadi di dalam sel. Garam tetrazolium berwarna kuning akan direduksi di dalam sel dengan bantuan enzim suksinat dehidrogenease yang kemudian menghasilkan kristal formazan (berwarna ugnu), nantinya kristal formazan akan terbaca absorbansinya dengan menggunakan ELISA reader pada panjang gelombang $550 \mathrm{~nm}$. Jumlah formazan yang terbentuk berbanding lurus dengan aktifitas enzimatik. Jika intensitas warna ungu semakin pekat, maka jumlah sel hidup semakin banyak (viabilitas sel tinggi).

Hasil pengolahan data nilai $\mathrm{IC}_{50}$ gandaria didapatlah $\mathrm{IC}_{50}$ dari ekstrak daun dengan pelarut n-heksan, etil asetat dan methanol dapat dilihat pada table 5 berikut ini.

Tabel 5 Nilai IC 50

\begin{tabular}{ccc}
\hline \multicolumn{2}{c}{ GANDARIA } & IC $5 \mathbf{5 0}(\boldsymbol{\mu g} / \mathbf{m L})$ \\
\hline \multirow{3}{*}{ DAUN } & N-Heksan* & 2880,471 \\
\cline { 2 - 3 } & Etil Asetat $^{*}$ & 436,966 \\
\cline { 2 - 3 } & Methanol* $^{*}$ & 665,806 \\
\hline \multirow{3}{*}{ BATANG } & N-heksan & 292,044 \\
\cline { 2 - 3 } & Etil Asetat* & 85,692 \\
\cline { 2 - 3 } & Methanol & 803,029 \\
\hline
\end{tabular}

Berdasarkan data $\mathrm{IC}_{50}$ yang memenihi syarat diperoleh aktivitas paling baik ditunjukkan pada sampel ekstrak n-heksan batang gandaria dimana nilai $\mathrm{IC}_{50}$ nya paling rendah, dimana semakin rendah nilai $\mathrm{IC}_{50}$ maka semakin baik aktivitas sitotoksik dari sampel hasil pengujiannya. Ekstrak n-heksan batang gandaria termasuk kedalam kategori lemah dengan nilai $\mathrm{IC}_{50} 292,044 \mu \mathrm{g} / \mathrm{mL}$ berdasarkan tabel 5 diatas. Adapun ekstrak etil asetat daun termasuk kedalam kategori lemah dengan rentang nilai $\mathrm{IC}_{50}$ 201-500 sedangkan ekstrak methanol batang termasuk kedalalm kategori tidak toksik $\mathrm{IC}_{50}>500$

\section{Kesimpulan}

Berdasarkan hasil penelitina yang telah dilakukan dapat diperoleh nilai $\mathrm{IC}_{50}$ dari ekstrak etil asetat daun 436,966 $\mu \mathrm{g} / \mathrm{mL}$, ekstrak n-heksan batang 292,044 $\mu \mathrm{g} / \mathrm{mL}$ dan ekstrak methanol batang 803,029 $\mu \mathrm{g} / \mathrm{mL}$. Dapat disimpulkan bahwa aktivitas sitototksik paling baik ditunjukan oleh sampel ekstrak n-heksan batang dan tergolong lemah 


\section{Ucapan Terimaksih}

Terimakasih kepada Fakultas Farmasi dan Lembaga Penelitian dan Pengabdian Masyarakat Universitas Bhakti Kencana, atas dukungannya dalam penelitian ini.

\section{DAFTAR PUSTAKA}

Choma., Irena, M.,Edyta, M.G. 2010. Bioautography Detection in ThinLayer Chromatography. Journal of Chromatography A Chroma351708 .

Dirjen POM. Farmakope Indonesia, Edisi IV. Jakarta: Departemen Kesehatan RI, 1995. Hal 7

Harborne, J.B. Metode Fitokimia. Penuntun Cara modern mengekstraksi Tumbuhan (Koasish Padmawinata dan Iwang Soediro, penerjemah). Bandung: ITB, 1987. Hal 103-104

Heyne, K., 1987, Tumbuhan Berguna Indonesia, Jilid Ketiga, Departemen kehutanan Badan Penelitian dan Pengembangan Kehutanan, Yayasan Sarana Wahana Jaya (Penterjemah), Jakarta.

Holt, G. J., Krieg, N. R., Sneath, A. H. P., Staley, T. J., Witirams, T. S. 1988. Bergey's Manual Od Determinative Bacteriology. London :Wiliam\& Wilkins Company. P. 187.

Jawetz, E., Joseph, M., Edward, A. A., Geo, F. B., Janet, S. B., dan Nicholas, L. O. 2001. Mikrobiologi Kedokteran. Edisi I Penerjemah : Mudihardi, E., Kuntaman., Wasito, E. B., Mertamiasih, M., Harsono, S., Alimsardjono, L. Jakarta : Penerbit Salemba Medika. Hal. 357.

Kurniawan, M.B., \& P. Bayu. 2010. Mengenal HewanDan Flora Asli Indonesia. Cikal Aksara. Jakarta.

Lee, C. Y., Simpson, K.L \& Gerber, L.1989. Vegetables as a major vitamin a source in our diets.Food Life Sci. Bill 126:1-11

Markham KR. Cara Mengidentifikasi Flavonoid. Bandung : Penerbit ITB. 1988. Hal 58-60

Mursyidi, A., 1990, Analisis Metabolit Sekunder, Gadjah Mada University Press, Yogyakarta, 175-180

Parker, S. 2009. Ensiklo pedia Tubuh Manusia, diterjemahkanWinardini, 162. Jakarta. Erlangga.

Pratiwi, S. T, 2008. Mikrobiologi Farmasi. Erlangga . Jakarta.

Prayetni., 2007, Gambaran Umum Kanker Leher Rahim,Direktorat Bina Pelayanan Keperawatan, Jakarta. dalam Darmawati, D., 2010, Kanker Serviks Wanita Usia Subur, Ideal Nursing Journal, 1(1), pp.09-13.

Poerwono, 2012. Kimia H., 2012. Kimia Organik I. DepartemenKimia Farmasi, Falkutas Farmasi Universitas Airlangga Surabaya. Page 15-16.

Rehatta,H. 2005. Potensi dan pengembangan tanaman gandaria (Bouea macro phylla Griffith) di desa Soya Kecamatan Sirimau, Kota Ambon. Laporan Hasil Penelitian. Lemlit. Universitas Pattimura. Ambon

Rifai, M.A., 1992. Bouea macrophylla Griffith. In Coronel, R.E. \& Verheij, E.W.M. (Eds.): Plant Resources of South-East Asia. No. 2: Edible fruits and nuts. Prosea Foundation, Bogor, Indonesia. pp. 104-105.

Robinson, T. 1995 : Kandungan Organik Tumbuhan Tinggi diterjemahkan oleh Kosasih Padmawinata, ITB,Bandung.

Roni, A, et al. 2019. "Uji Aktivitas Antibakteri Tumbuhan Gandaria (Bouea Macrophylla Griff) Terhadap Staphylococcus Aureus Dan Escherichia Coli." Jurnal 
Farmagazine, vol. 6, no. 1, pp. 1721

Sinay, H. 2011. Pengaruh Giberalin Dan Temperatur Terhadap Pertumbuhan Semai Gandaria (Bоиea macrophylla Griffith). BIOSCIENTIAE 8: 15-22.

Tangkuman, C. 2006. Identifikasi Potensi Tanaman Gandaria (Bouea macrophylla Griff) Di Dusun KusuKusu Sereh Desa Urimesing Kecamatan Nusaniwe Kota Ambon. [Skripsi]. Fakultas Pertanian Universitas Pattimura. Ambon

Vesheji dan Coronel, 1992, Edible fruit and Nuts, Prosea Plant Resources of South east Asia No.2, Pudoc-DLO, Nederland,Page 104-105

Vogel, 1994, A Textbook of Quantitative Inorganic Analysis, alih bahasa oleh Pudjaatmaka, H. A., dan Setiono, L., EGC, Jakarta, 846-848 